
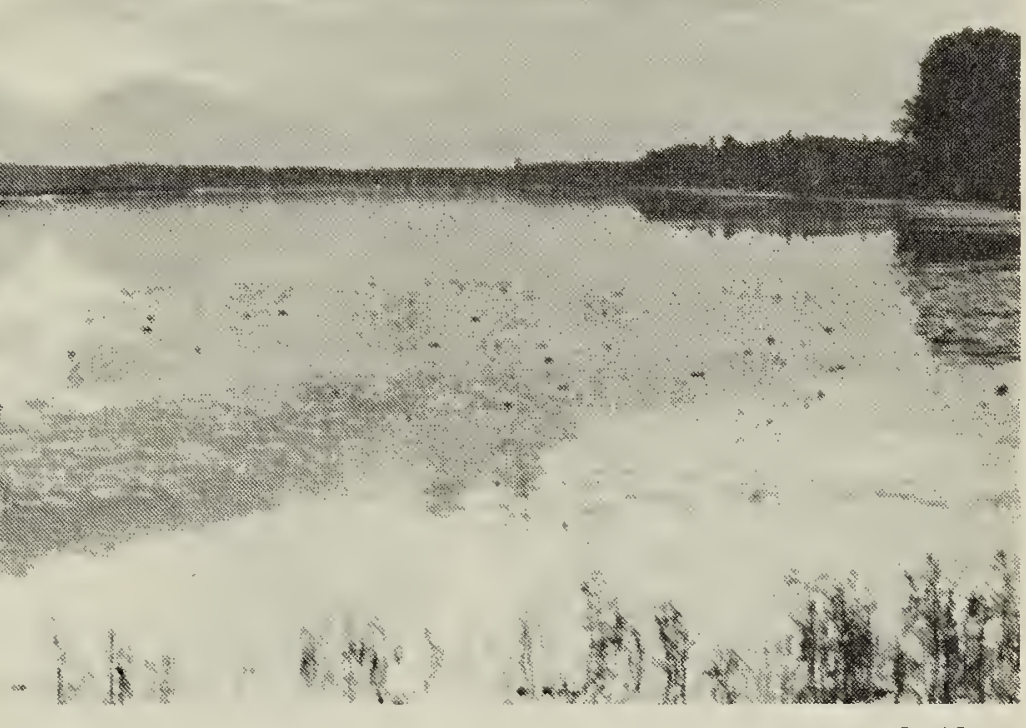

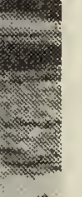

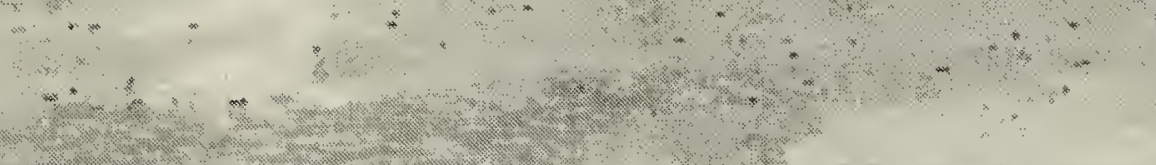

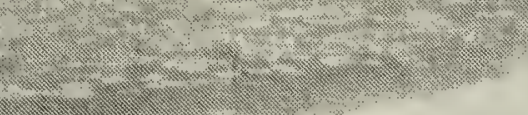

Bruce McKee

\title{
WE ARE EARTH AND FIRE, WIND AND WATER: ONE NORTHERN SUMMER
}

\author{
by THOMAS J. BURNS*
}

I am glad I shall never be young without wild country to be young in. Of what avail are forty freedoms without a blank spot on the map? - Aldo Leopold

During the summer of 1973, two inoes followed some of the historic ver systems of northern Saskathewan, fulfilling many dreams and lising many hopes for the future of he North and its people. This story is bout Wilf Allan of Nova Scotia (who arted it all), Tom Burns of Regina, ruce McKee of Saskatoon, Jan Olafon of Saskatoon (who we wish had een able to make the entire trip), llan Wickstrom of Tompkins, our ogs, Brownie and the Squeekers, and

3424 College Ave..

legina, Saskaltchewan.

$4 \mathrm{~T}$ iW 4 all the people who made the trip what it was.

It was the beginning of July when our two 16-foot cedar-canvas canoes set out from Meadow Lake Provincial Park bound for Cumberland House 630 miles and 6 weeks distant. A week of preparation on the many lakes and streams of the park had already assured us of an easy paddle through the coming miles of marsh grasses, rushes and water lilies. A light breeze came up to fill our hastily improvised sails; ducks rose out of the thick growth; terns (right and left!) circled overhead; a Great Blue Heron took to 


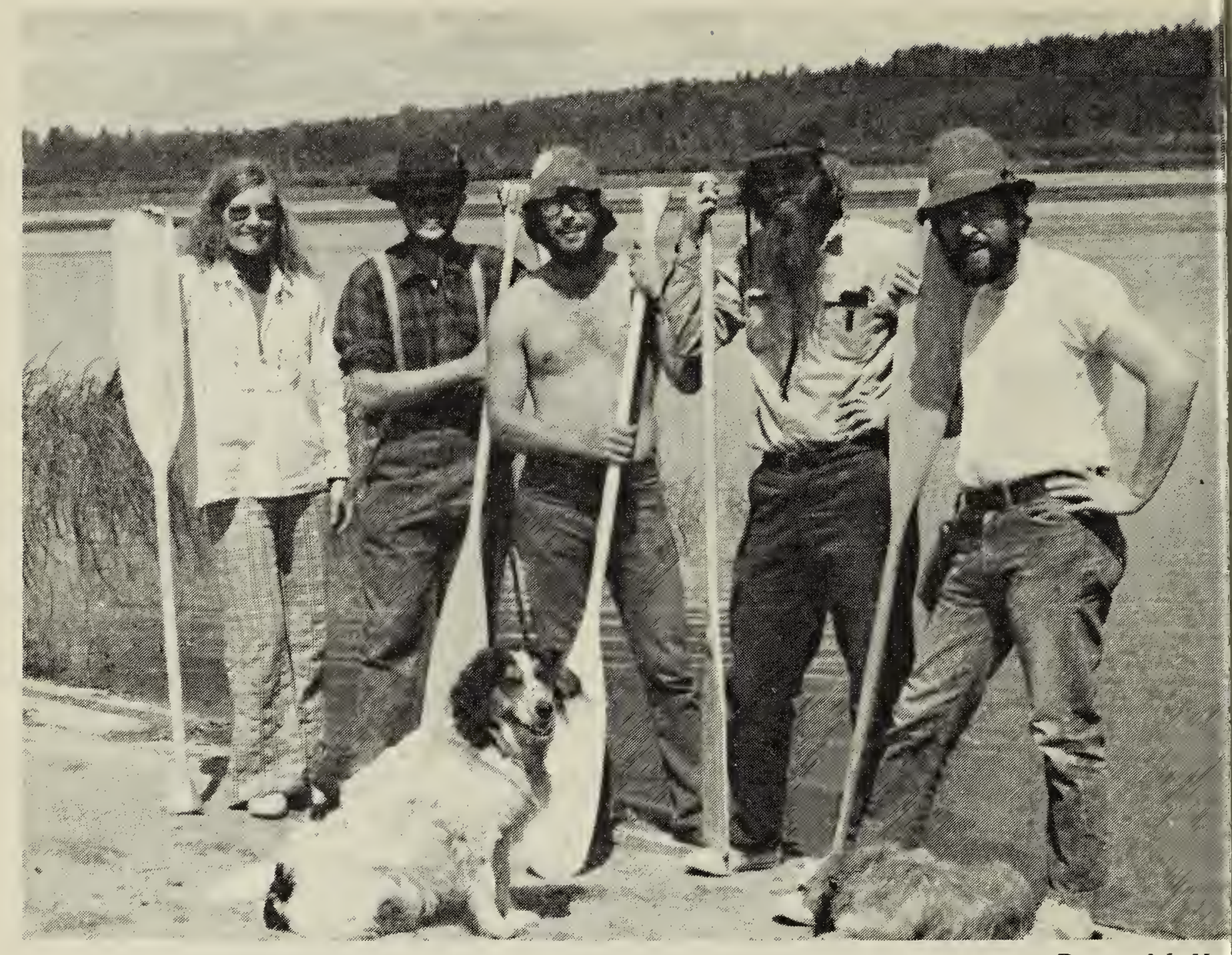

Bruce McKe

Left to right: Jan Olofson, Tom Burns, Allan Wickstrom, Bruce McKee, Wilf Allan, witl "the Squeekers" and "Brownie" in the foreground.

the wing near our boats; marsh birds protested our intrusion but it was the pelicans that excited us - soaring, floating on invisible currents in a cloudless sky. That first night the stars were barely visible, obscured by the brightness of the moon, and the loons called out from the stilled and shining waters, answered only by distant echoes.

The lower Waterhen River, outside the park boundaries, alternated between fast water, where the shallow bed was strewn with quickly passing boulders, and slow meanders where the river was swallowed up in broad valleys. Periodically we came upon trappers' cabins, staring out over the river from clearings high above the banks. The land was rich: moose, deer, bear, muskrat, Golden Eagles, waterfowl and, of course, pelicans. One of our camps was made at a long abandoned homestead; the imposin ruins of the cabin, barn and out buildings were testimony to fade dreams of long ago in this lush an gentle wilderness. But if we wer merely escaping from the reality r world crises, our success was littl greater than was this homesteader's i the long run, for throughout the da we heard muffled explosions, as on possible future was rehearsed on th nearby air weapons test range.

Soon we left the Waterhen for th Beaver River where the general floo conditions all across the North becam more apparent. The rapids, known ts earlier voyageurs as "Grand", now ap peared most unworthy of the name bearing only hints of the white horse and swift waters of other years. We sav no wildlife along the high, steep bank 
f mixed softwoods, but as the river alley widened into marshlands on the llowing days, pelicans and every ind of waterfowl again accompanied s, past the small community of Beauval and on to Beaver River, a ishing settlement located where the iver flows into Lac Ile à la Crosse. We rossed the lake, arriving at historic le a la Crosse to find the Co-op and he Bay closed and the annual sports fay in progress. We took several days o reorganize our jumbled packs and isit Nap Johnson, an unforgettable character, who combines legendary horthern hospitality with an amazing knowledge of the bush. He spent a day with us, drawing from memory maps of he rapids we would encounter up to Otter, giving us advice on paddling and snaring, or demonstrating the proper method of making trapper's bannock. He spoke of some of the problems of this northern community, which still must import fish crates and telephone poles from as far away as Cumberland, despite their attempts to obtain assistance for a sawmill to employ local labour. This was not to be the last time we would encounter realistic alternatives for community development that did not enjoy the favour of the government. Nap was busy trying to finish some of the cabins for his Alstead Lake Camp in time for fall hunting but he expressed a powerful longing to join us. Jan, unfortunately, had to return to Saskatoon, leaving us to push on. That evening, as we crossed the lake, now paddling Indian style, we passed more than 100 pelicans gathered on a rocky point beyond one of the many small islands we passed. Several took to the air, sharply silhouetted against the sinking sun.

Lac Ile à la Crosse is long and narrow; at some points the waters stretch as far as the eye can see, north and south. The winds can roll up huge waves by mid-morning and the swell does not die until late at night. The

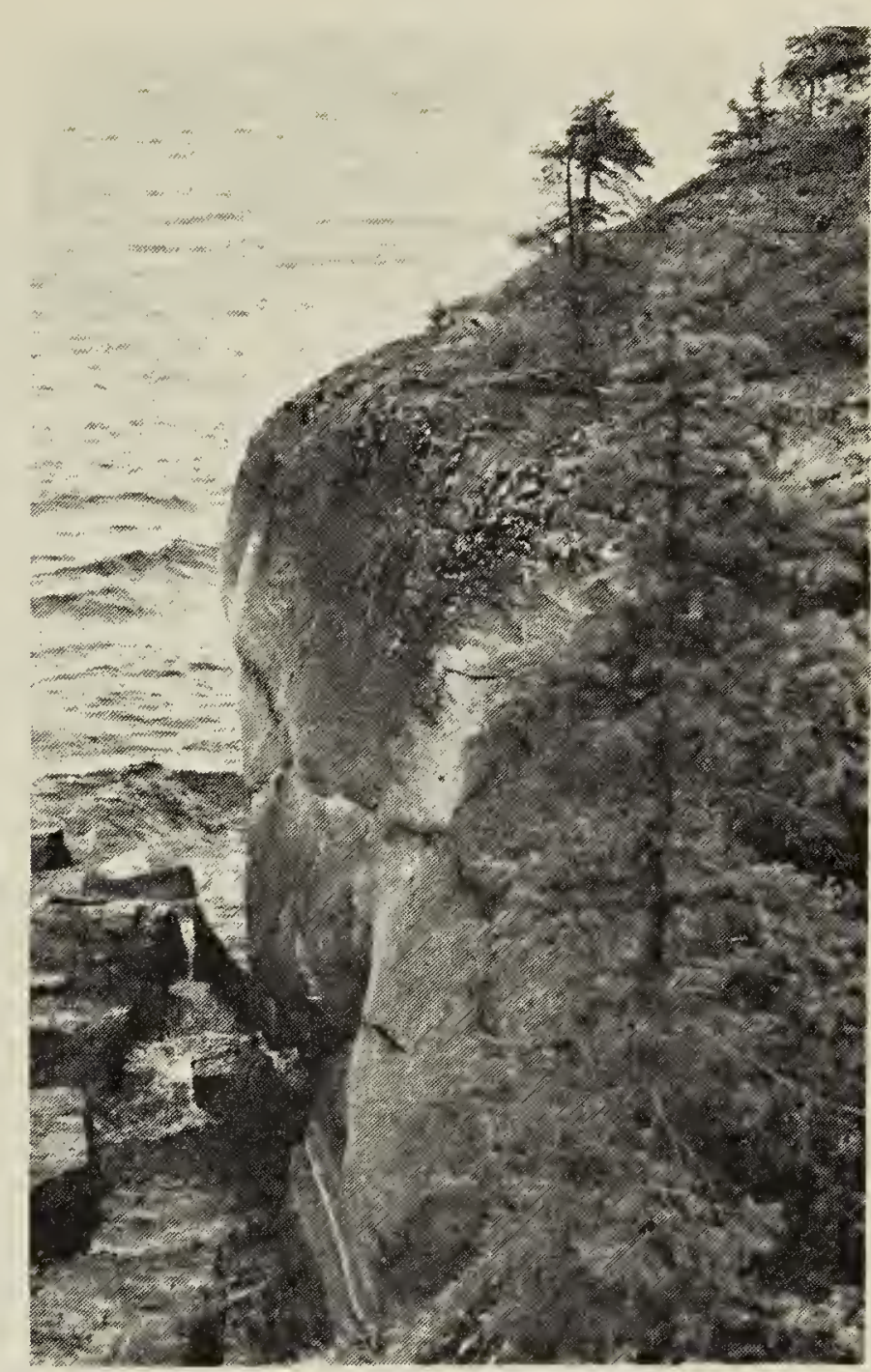

Dipper Lake

Bruce McKee

clouds are spectacular, caught between the blues of sky and lake.

We were windbound for a good part of the time but our patience was soon rewarded with a tail wind that pushed us up the lake. We sighted our first Bald Eagle of the trip perched atop a dead poplar in the evening sun - a most magnificent bird. At the north end of the lake, just past Shagenaw Rapids lay Patuanak, gateway to the Churchill and to the Canadian Shield, our last provisioning point before Missinippi. Our tents pitched beside the Hudson's Bay Post, we eagerly awaited the sunrise. In our excitement that morning we missed the outlet of Shagenaw Lake, but eventually reached Drum Rapids, after passing a cross erected to Louis Riel's sister, who had hidden here during the illfated uprising of 1885 . This was the Churchill at last: Leaf, Deer and Dipper Rapids, each more spectacular 


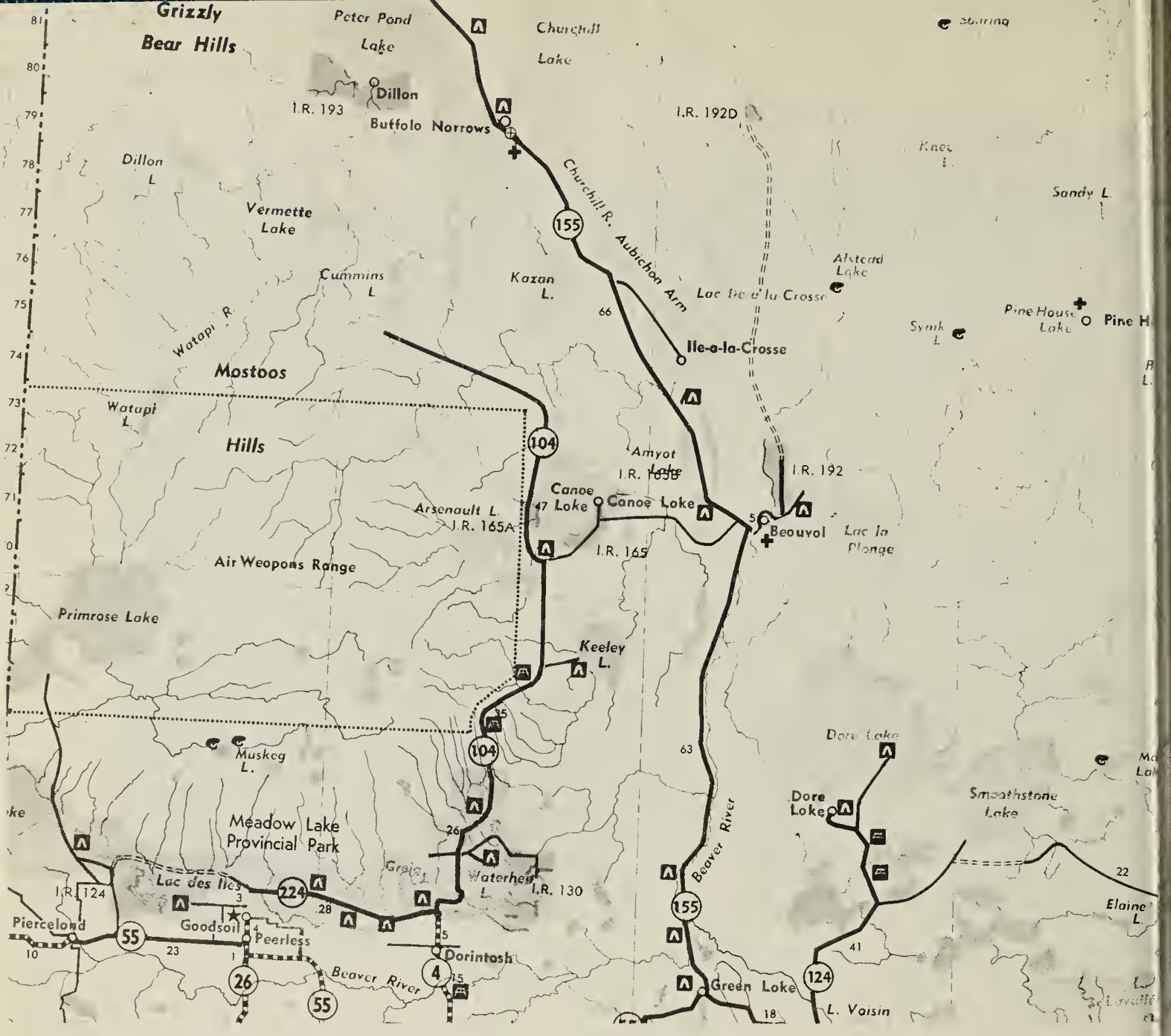

Churchill River from Peter Pond Lake to Manitoba.

than the other. But after this brief introduction, we encountered the other face of the Churchill, paddling through winding channels of calm water to Dipper Lake, camping on an island for a lazy day of exploring, picking saskatoons and blueberries, fishing and, finally, watching a fiery sunset over the distant shore. After crossing Primeau Lake on a calm day, past Primeau village where Father Moraud had built his small church overlooking the river, we attempted running Crooked Rapids but one of the canoes capsized in the unusually fast current. The better part of the day was spent drying gear, repairing a broken gunnel and surveying the rapids to try to see how we managed such foolishness. The rough-hewn pine gunnel, however, became a sort of status symbol, serving us well for th rest of the journey. We finished th lower set of Crooked in better forn and camped just above Knee Rapids where we waited to portage the gea and the damaged canoe in the mor ning. As we made the second trip o the portage - we always made twe trips, one for the gear and one for the canoe - we narrowly missed an en counter with a bear who made off with our marmalade and detergent, hotly pursued by Squeekers, our intrepic bear dog. Again we reorganized oul gear before pushing off for one of the finest days of the summer on Knec Lake.

It was calm as we set out, but soon we were pushing against the strongest winds and waves and the hardest rain of the trip. We pulled into a small 


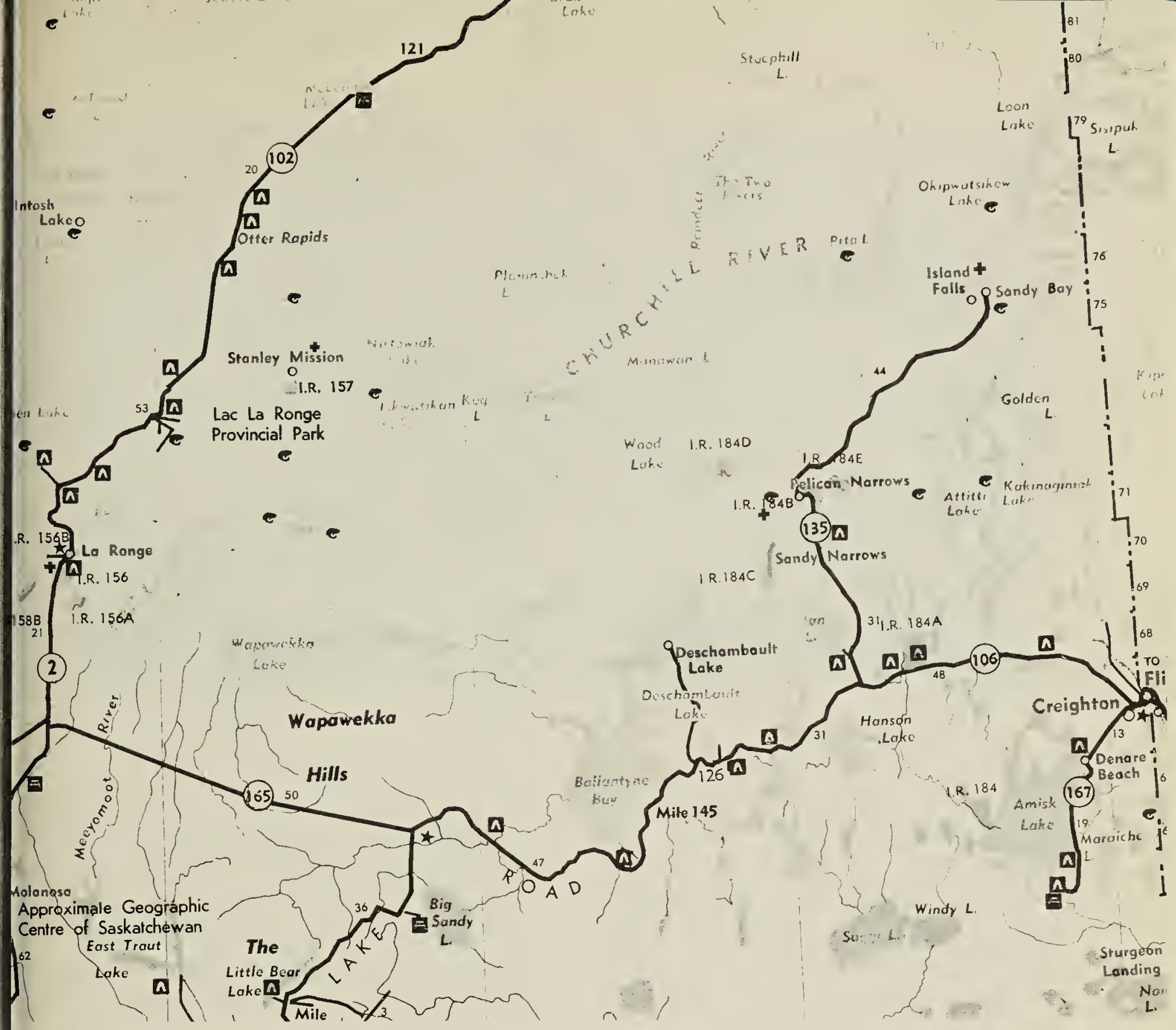

orseshoe cove at the entrance to entley Bay, marked by another cross rected high upon a hill that rose arply from the lake. We brewed ome hot chocolate and huddled round a large fire built under a neltering pine as the rain finally urned to mist. We left quietly, addling down the mirror-like surface $f$ the bay - the sun, the clouds, the ind, the rocks, the trees, the mists, he rain and the birds left a tangle of lemories. The colour was red, a touch i the sky and a bold stroke across the ocks, seen through the lifting haze, ut of which gulls flew as if from a oid, passing overhead and again into he mist. The cry of the loon echoed hrough countless foggy bays. We slept ite in the gentle morning rain but put $h$ a full day of paddling when we were unable to find a campsite in the Haultain Marshes until we had reached Snake Rapids.

The rapids along this part of the river were sheer joy and we stopped for a mid-afternoon swim on a sandy beach overlooking Cowpack Island and the burned-over shores of Snake Lake. We lost ourselves completely in Sandfly Lake, a collection of islands and rocks strewn helter-skelter from one end to the other, a pleasant detour that taught us to put the compass ahead of our own intuition. At Needle Falls, with its glassy ribbons of black water rearing up and exploding beside our tents, we prepared for a difficult day of navigation through Black Bear Island Lake where Nap had alerted us to an Indian pictograph (mentioned in the journal of Alexander Mackenzie). 
Silent Rapids marked the entry to this lake on a five-eagle day that left a swirl of memories: a granite cliff face leaping out from the calm waters, a lone jackpine standing in a clearing, island after island of dark spruce stretching off into the hazy distance and a sudden storm passing over on a southwest wind. As we passed the Foster River, for the first time the waters were crystal clear and free of algae. We had the first of our many encounters with the Keche Mookoomanuk, the long knives, the American tourists found throughout the North in relentless search for the legendary great northern - jackfish to us. By the next morning we were thoroughly drenched and a fire was out of the question as long as the rain continued. We listened to the loons calling from every corner of this tangled lake.

We shot, portaged and lined the series of rapids that followed, but spent a quiet evening of reflection at the Lake of the Dead, recalling our breathless excitement and anticipating our coming return to "civilization" symbolized by the great steel bridge: Otter Rapids, one day and over a mil of portages away. We could obtain $n$ information on the Devils an cautiously resigned ourselves to th long portages. We arrived at Otter tha evening and camped at the bridge to await an attempt at these famou rapids by Wilf and Allan. Soon afte passing the shack tents of the nativ guides along the shore, we were i Missinippi, washing, showering and resting. Friends were to meet us her with provisions and we passed at evening with Peter Whitehead, a loca canoe outfitter, who presented us witl a magnificent set of maps for the res of the trip and related some of hi many experiences in the North.

Bruce and I went into La Ronge, the new "capital of the north", to visi friends and savour the alien and op pressive atmosphere as the forces $o$ white progress march relentlessly ahead. Wandering through the air conditioned government offices,

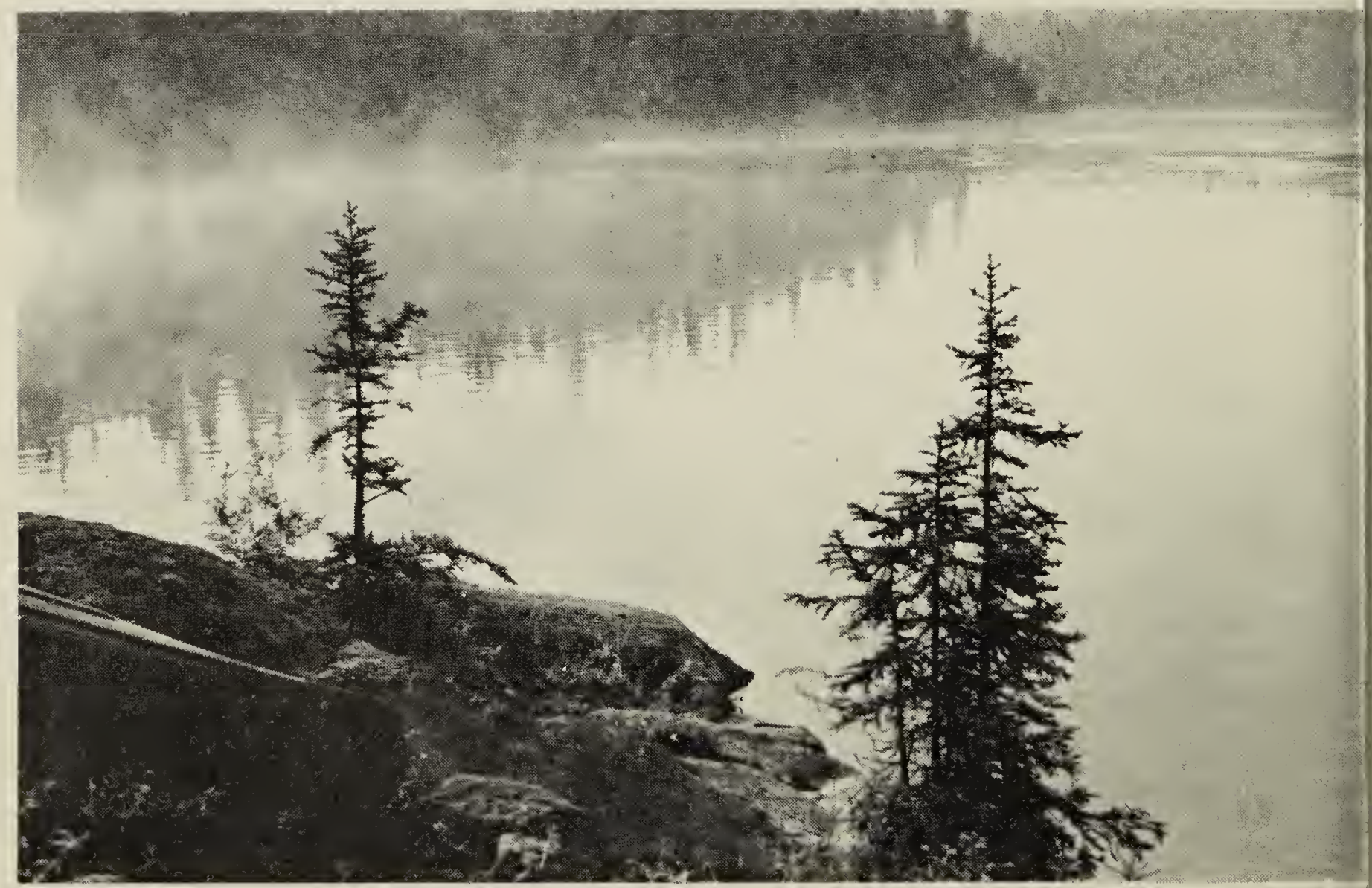

Black Bear Island Lake

Bruce McKee 


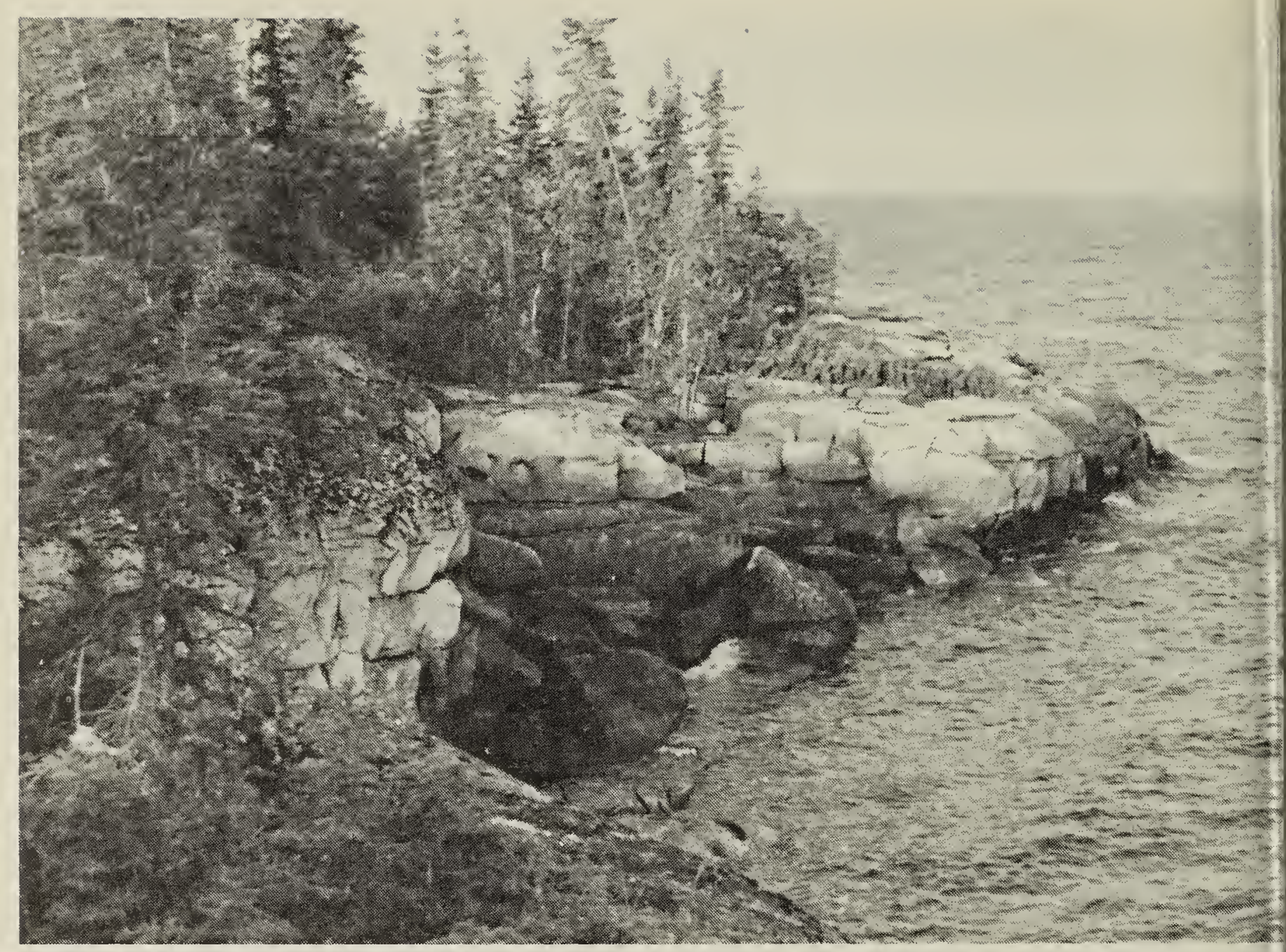

Namew Lake

Bruce McKee

end of one part of our trip but perhaps the last time we would ever see these people in their own land.

We paddled through the shallow winding channels leading to Wood Lake and camped on a high, narrow spine of rock rising sharply from the water. A spectacular sunrise the next morning started us off down the lake where the light and shade played on the islands and the shore, revealing the reds, oranges and yellows of autumn. We kept our eyes open for the pelicans which we had missed since Black Bear Island Lake, expecting them to reappear near Pelican Narrows, but to no avail. We followed the meanders of Grassy Narrows, and pitched our tents along a low rock shelf facing the morning sun. The evening star was set in a glowing blue sky, an infinity beyond the rows of dark spruce and brightly coloured birches just across the river. We portaged the next two small rapids before arriving at a particularly cleat pictograph of a Mannigishi with his si fingers on each hand and six toes or each foot. We neglected to leave the traditional offering for good luck.

We shot Medicine Rapids, the las before Pelican Narrows, where we lef our canoes behind to fly to Sandy Bay returning to Churchill for a visit witl my brother, Peter Burns, who took u up the river in his motorized canoe an exhilarating experience after weeks of paddling! We again met Pete Gregg, preparing another book for the canoe route series, and passed an evening comparing notes on the progress of the governmen engineering crews. We visited the Hudson Bay Mining and Smelting dam at Island Falls and marvelled at the deserted townsite with its cement walks, fire hydrants and recreation hall. The 34 houses with their finished basements and sunny porches had sat 
pty for 7 years since the dam was tomated and the requests by the mmunity to develop the site as a mily resort had fallen on deaf ears. he people, who had seen the end of eir fishing and trapping and later st their jobs at the dam, were wary of e promises and claims made for droelectric and diversion schemes. twilight drive brought us back to lican Narrows, anxious to resume ir journey.

We were blown down Mirond Lake a northwest wind to the beginning the Sturgeon Wier River at Corille Rapids. In a minor rapid just st the next portage, the mischievous annigishi grasped the gunnels of my noe and gave me a second soaking It we soon dried out under the afteron sun. At Dog Rapids we had our venge, avoiding the portage by slipng along a little passage through the illows. As we passed Maligne Lake id the bridge at Mile 190 of the Hann Lake Road, we again had a strong irrent and rapids reminiscent of the hurchill. Wilf and Allan shot Leaf apids but we all portaged Scoop, a hall but spectacular fall, surrounded spruce, set against the clear blue $y$. The wildlife, conspicuously absent ong the Churchill returned here: erons, hawks and pelicans, as well as e ever-present eagles. Allan even anaged to call up a loon! Snake apids provided a high point for Wilf id Allan, who narrowly missed a ige rock in this long and difficult apid that could have ended the brief ireer of Wilf's Kildonan canoe. For ruce and myself, under the weather nd the previous night's cooking!), the prtage was difficult and help with our Inoe was much appreciated as was the llowing day of rest. On the second ght of our layover we were treated to spectacular display of lightning that ent brilliant flashes of whiteness rough the stillness of the forest. Just ast a small Indian burial ground verlooking the river lay Spruce
Rapids, with its pretty portage and campsite littered with dead fish, rotten garbage, cans and beer bottles.

As we crossed Amisk Lake we bade farewell to the Shield, noting the bright orange lichens covering the limestone cliffs along the shore. Then we encountered the power boats from the resorts near Flin Flon, clearly marked by the distant stacks and smoke plume on the horizon. By late afternoon we reached the DNR campsite at the end of the lake where we met Bud Holm, a Winnipeg artist, painting wildlife of the north.

This next part of the Wier was also known as the Rivière Maligne, a name that caused me some concern until I realized it has been applied by upstream travellers! Our only detailed maps for the river to Sturgeon Landing were drawn by Peter Whitehead from aerial photographs and indicated 17 sets of rapids through the 100-foot drop and 20-mile run. We shot them all, including Crooked, which brought back memories of the Churchill, both in name and difficulty, on the most exhilarating day of the entire summer, a blur of birch and poplar, rocks and bears along the shore. We took water several times and one canoe was ignominiously grounded in the middle of L'Isle Rapids. The last $2 \frac{1}{2}$ miles to Sturgeon along Goose Creek was literally a continuous rapid, passing in a flash and ending abruptly as we sped past the docks at Namew Lake quite unable to stop.

We were all anxious to leave this tourist trap the next morning but our attempt at crossing Namew was partially thwarted when Bruce and I turned back in the face of strong head winds. It was a North Superior day as huge waves crashed against the rocky shore but as night fell and a brilliant red moon coloured the quict waters, we paddled toward the distant beacon across the lake and rejoined Wilf and Allan. In the morning we set off 
through Whitey Narrows as waves of storm clouds passed overhead. A beaver swam just ahead of us, slapping his tail and diving whenever our canoes drifted too close for his comfort. Soon we reached Cumberland House - the island where there are many spruce trees - almost an anticlimax after one black cloud released its fury upon us as we stumbled clownlike in the rain and hail through the oozing mud flats that signalled our arrival at the Saskatchewan. The trip ended in a manner fitting the spirit in which it was taken - quietly and unceremoniously, as the sun set against a cloudy sky, burning into our memories the 6 weeks of the Great Lone Land and its people.

Epilogue: Butler, writing in 1870 , described Cumberland as unchanging, the same as it had been a century before but such is clearly no longer the case, if it ever was. The only thing that never seems to change is the grip that Western industrial society has on peripheral cultures and their lands - in Africa, in South America and even in northern Saskatchewan. We are still missionaries but now we are trying to sell our goods and services to the non-believer by destroying his sense of self-reliance. It is little wonder our society is so drawn to the wilderness experience in trying to recapture the spirit of human dignity. but so surprising that we refuse to understand why many of those who retain their dignity refuse to accept our ideals willingly. Remember that the North does not belong to us, nor to those holding legal title to the land, but to its people, who do not own the

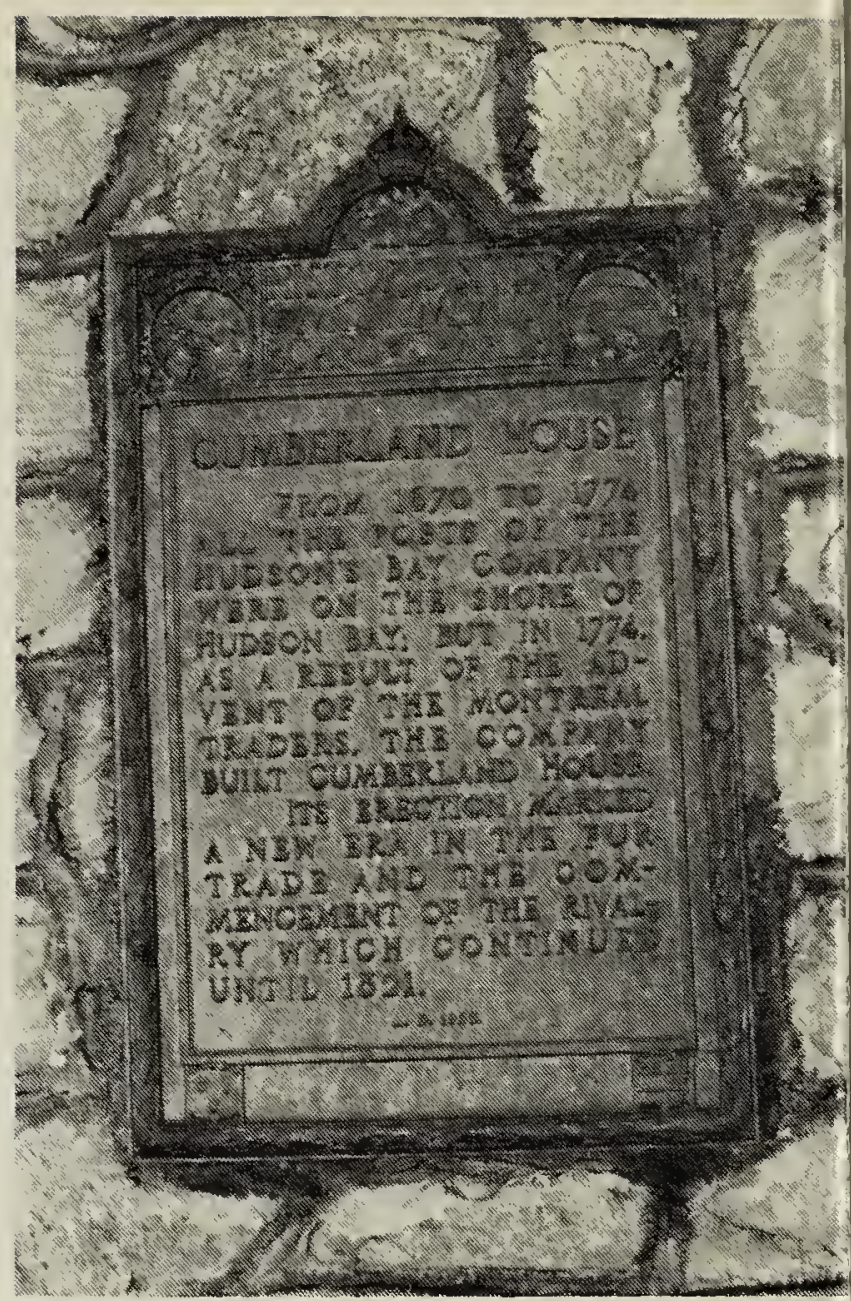

Bruce McKe

Historic marker at Cumberland House

land but only know it, and in that, kno themselves.

For afterwards a man finds pleasure in his pains, when he has suffered long and wandered long. - Homer

\section{SUGGESTED READING}

KEMP, H. S. M. 1956. Northern trader. Ryerso? Toronto.

MORSE, Eric W. 1971. Fur trade can routes/Then and Now, Queen's Printer, Ottawi

OLSON, Sigurd F. 1961. The lonely land, Knop New York.

In wildness is the preservation of the world.

Henry David Thoreau, Walking. 